\title{
Effect of Aging on Corrosion Behavior of Martensite Phase in Cu-Al-Be Shape Memory Alloy
}

\author{
Jafer T. Al-Haidary \\ Ali M. Aldulaimi \\ Ahmed A. Hamza \\ Dept. of Prod. Eng. \& Metallurgy, University of Technology, Baghdad - IRAQ \\ jalhaidary@yahoo.com \\ engalimmd75@gmail.com \\ ah_azez1583@yahoo.com \\ Received: 25-Oct.-2017 \\ http://doi.org/10.29194/NJES21010127
}

\begin{abstract}
The corrosion behavior of martensite phase in $\mathrm{Cu}-\mathrm{Al}-\mathrm{Be}$ shape memory alloy with aging at $150^{\circ} \mathrm{C}$ at time 2,4and 6 hour and quenching ice water with salt, water at room temperature and oil media study by open circuit potential, tafal polarization and cyclic polarization. The microstructure of martensite study by optical microscope and $\mathrm{x}$-ray diffraction(XRD) and transformation temperature was determined by Differential Scanning Calorimeter (DSC).the result show aging martensite at $150^{\circ} \mathrm{C}$ at 2 and 4 hour have high open circuit potential, low corrosion current density, high corrosion potential and pitting potential than martensite without aging.
\end{abstract}

Keyword: $\mathrm{Cu}-\mathrm{Al}-\mathrm{Be}$ shape memory, martensite phase, corrosion behavior.

\section{Introduction}

$\mathrm{Cu}-(13$ wt. \%)Al shape memory alloys with addition small amount of beryllium prone superelastic effect at room temperature, because the martensitic transformation from the austenite phase $(\beta)$ have $\mathrm{BCC}$ crystal structure to martensite phase(18R) have monoclinic crystal structure . The application of these alloy used as absorb vibration damping effect in bridge and building structure heat treatment of this alloy like quenching from high temperature and then aging at different temperatures and time led to formation of different phases, and their Presence can affect their shape memory effect and corrosion behavior . In realistic applications, as the alloy is exposure to corrosion solution for a period of time they are exhibit to corrosion and pitting, for that reason study of corrosion behavior like corrosion current and potential and pitting potential of the alloys are require to be done before they are put into biomedical and industrial applications. Since SMAs find a wide application in the marine, aerospace applications and it is also used in the surgical medical use such as guide wire, so it becomes necessary that the shape memory alloys high corrosion resistance to the environment in which it is being used, aim of this search it is important to evaluate the corrosion current, corrosion potential and pitting potential of the SMAs that used in biomedical applications [1].

\section{Experimental work}

The master alloy of chemical composition $\mathrm{Cu}-$ $13 \% \mathrm{Al}-0.545 \% \mathrm{Be}$ was received as cast.. Homogenized at $800^{\circ} \mathrm{C}$ for $3 \mathrm{~h}$ within the $\beta$ phase region according to phase diagram and then betatized at $800^{\circ} \mathrm{C}$ for $30 \mathrm{~min}$ and quenching in salt ice water. Aging at $150^{\circ} \mathrm{C}$ at 2, 4, 6 hour and quenching in salt ice water, water and oil media. the samples with dimensions $5 \mathrm{~mm}$ length and 14 $\mathrm{mm}$ diameter are (grinding with different wet paper 120,320,500,1000, 2000 and wishing with water ,polishing with cloth diamond and lubricant using polishing device then samples wishing with water, etching with solution 5 gram $\mathrm{FeCl}_{3}, 10 \mathrm{ml}$ HCL and $100 \mathrm{Ml}_{2} \mathrm{O}$. X-ray diffraction device type (shimadzu XRD-6000 X-Ray diffractmeter). Differential Scanning Calorimeter (DSC) for determining transformation temperature start and finish of martensite and austenite by heating and cooling sample.Corrosion testing by carried out using open circuit potential, tafel polarization and cyclic polarization. Corrosion study by electrochemical cell contains solution 1 liter Table (1) Show simulation body fluid and inside container there are three electrodes and these electrode are contact to the potentiostatic Figure (1) Show wenking MLab model.

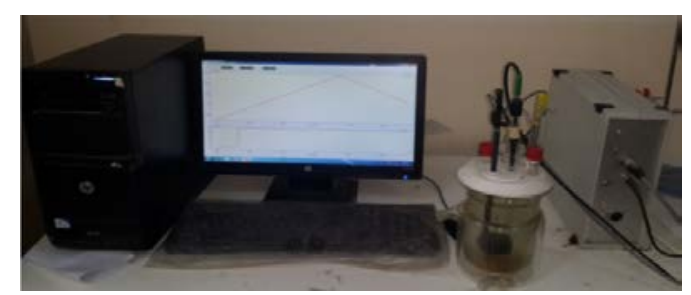

Figure 1: Cell connecting three electrode and potentiostat wenking MLab model.

Table 1: Percent of salt in distillation water of simulation body fluid at $\mathrm{pH} 7.4$ and temperature 37 C.

\begin{tabular}{|c|c|}
\hline salt & $\mathrm{g} / \mathrm{L}$ \\
\hline $\mathrm{NaCl}$ & 8.036 \\
\hline $\mathrm{KCl}$ & 0.225 \\
\hline $\mathrm{CaCl}_{2}$ & 0.293 \\
\hline $\mathrm{NaHCO}_{3}$ & 0.352 \\
\hline
\end{tabular}




\begin{tabular}{|c|c|}
\hline $\mathrm{K}_{2} \mathrm{HPO}_{4}$ & 0.230 \\
\hline $\mathrm{MgCl}_{2} \cdot 6 \mathrm{H}_{2} \mathrm{O}$ & 0.311 \\
\hline $\mathrm{NaSO}_{4}$ & 0.072 \\
\hline
\end{tabular}

Calculation of Corrosion rate from the Corrosion Current.

C.R. $(\mathrm{mpy})=\frac{0.13 \operatorname{Icorr}(E . W)}{d}$

Where:

Mpy= milli-inches per year.

Icorr $=$ corrosion current density $\left(\mu \mathrm{A} / \mathrm{cm}^{2}\right)$.

E.W=equivalent weight of the corroding species, (g).

$\mathrm{d}=$ density of the corroding species, $\left(\mathrm{g} / \mathrm{cm}^{3}\right)$.

\section{Result and discussion}

\subsection{Microstructure}

Microstructure of quenching from $800{ }^{\circ} \mathrm{C}$ in to ice water transform directly from austenite phase have BCC crystal structure to martensite phase have plate structure.

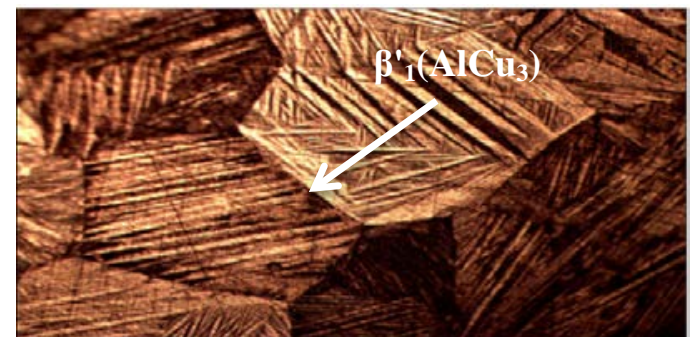

Figure 2: Martensite phase of $\mathrm{Cu}-\mathrm{Al}-\mathrm{Be}$ shape memory alloy at magnifications (10X).

Alloy that heat treatment at $800^{\circ} \mathrm{C}$ for 3 hour and quenching in ice water have martensite phase, and this martensite phase have $\mathrm{AlCu}_{3}$ phase. According to x-ray diffraction and standard cards, this x-ray diffraction identical with $\mathrm{AlCu}_{3}$ card.

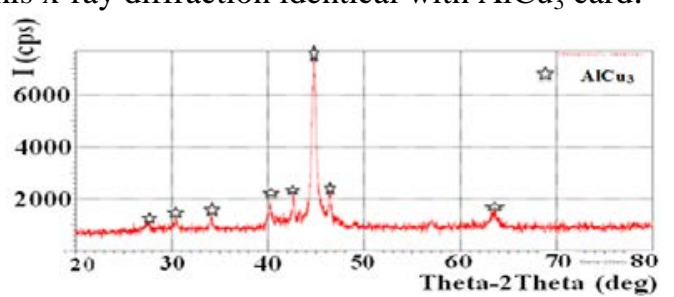

Figure 3: X-ray diffraction (XRD) of martensite phase.

\subsection{Aging treatment at $150^{\circ} \mathrm{C}$.}

After quenching from $800^{\circ} \mathrm{C}$, the samples were aging at $150^{\circ} \mathrm{C}$ in the martensite phase region according to phase diagram for 2,4 and 6hour and quenching ice water with salt, water and oil. The martensite transformation is not appreciably effected by $100 \mathrm{~h}$ at $220^{\circ} \mathrm{C}$ or $260^{\circ} \mathrm{C}$. Beyond annealing for $200 \mathrm{~h}$, at theses temperature, martensite transformation degradation is noticed caused by the precipitation phenomenon. The difference between martensite phases at aging $150^{\circ} \mathrm{C}$ have small and fine plate of martensite phase while as received have thick plate of martensite. martensite phase that quenched in different media ice water with salt, water and oil have very small little difference in thich of plate martensite phase therefore difficult recognize between them at microstructure . Figure (4), (5) and (6) show martensite phase at different aging time and quenching media at magnifications (10X).Aging in the martensitic state are termed 'stabilization of martensite. Primarily two mechanisms have been proposed for the stabilization of martensite. One is reordering in martensite, i.e., atomic rearrangement in martensite, the second mechanism for the stabilization of martensite is pinning of interfaces between parent and martensite and between martensite variants by quenched-in vacancies and/or precipitates [2-4].

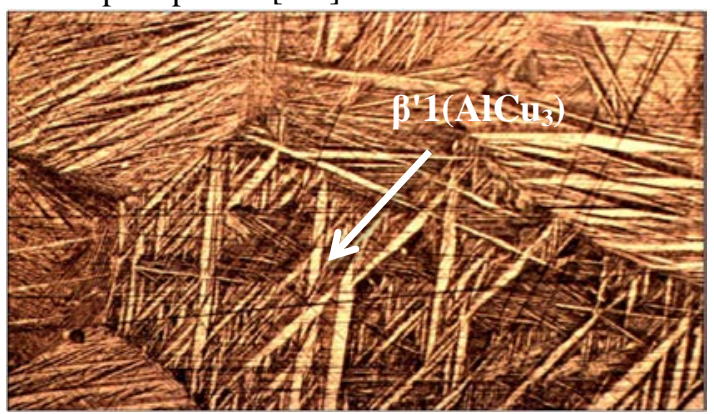

(a)

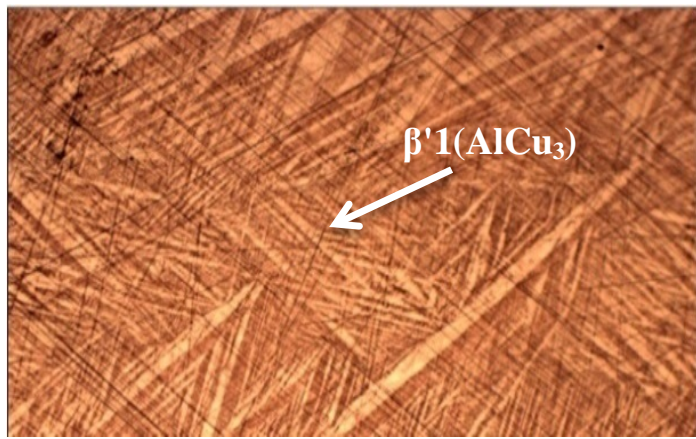

(b)

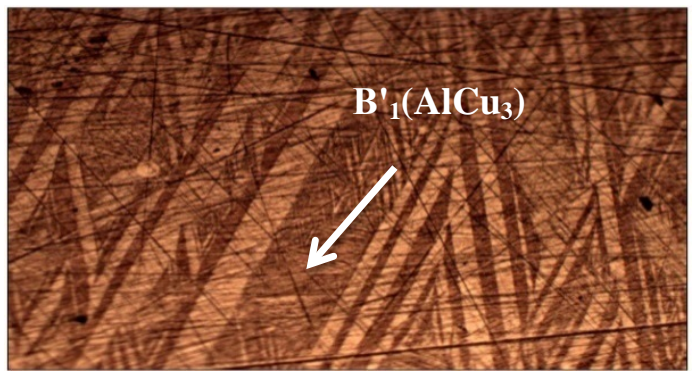

(c)

Figure 4: Effect of heat treatment on microstructure by optical microscope at magnification(10x).(a) $150^{\circ} \mathrm{C} 2 \mathrm{~h}$ salt ice water quenching (b) $150^{\circ} \mathrm{C} 4 \mathrm{~h}$ water quenching (c) $150^{\circ} \mathrm{C}$ $6 \mathrm{~h}$ salt ice water quenching. 


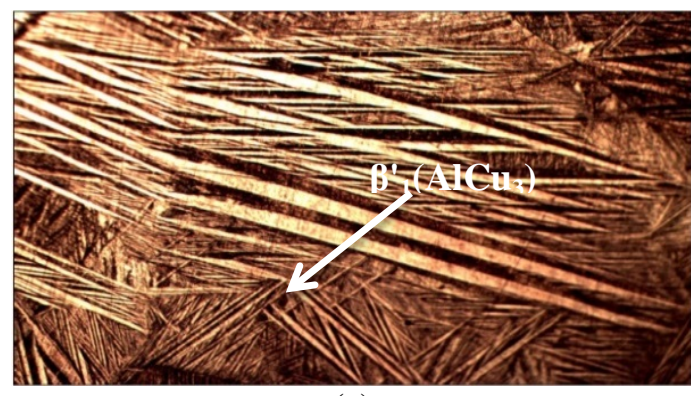

(a)

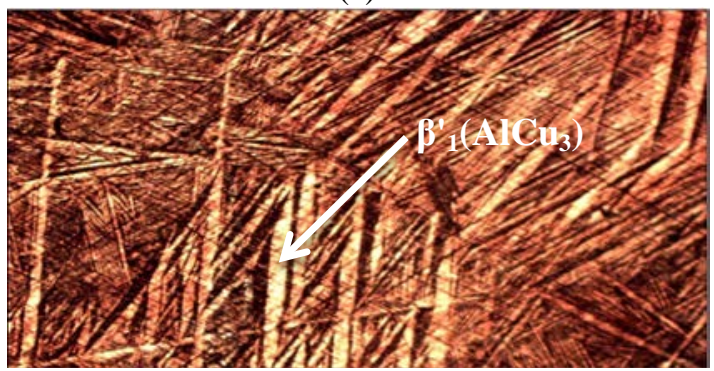

(b)

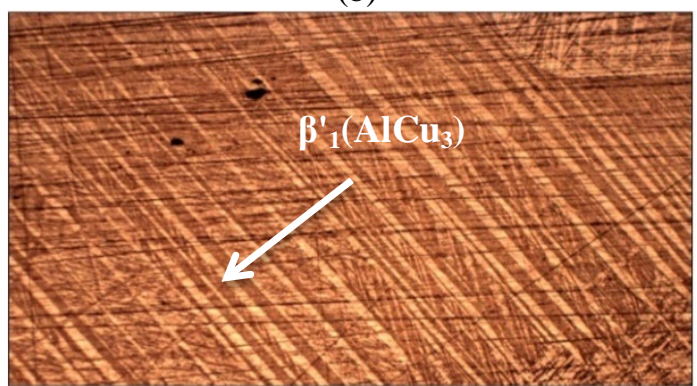

(c)

Figure 5: Effect of heat treatment on microstructure by optical microscope at magnification(10x).(a) $150^{\circ} \mathrm{C} \quad 2 \mathrm{~h} \quad$ water quenching(b) $150^{\circ} \mathrm{C}$ 4h water quenching (c) $150^{\circ} \mathrm{C}$ $6 \mathrm{~h}$ water quenching.

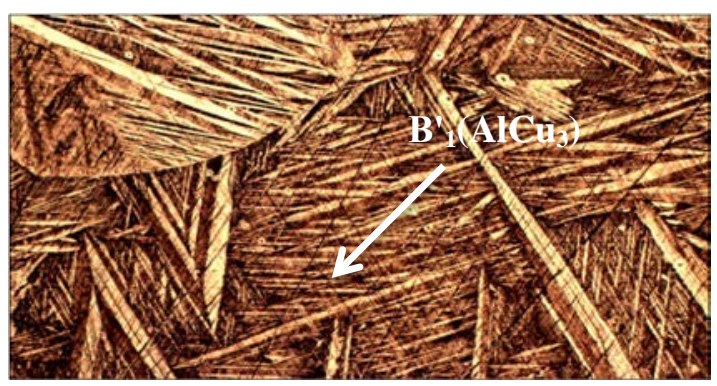

(a)

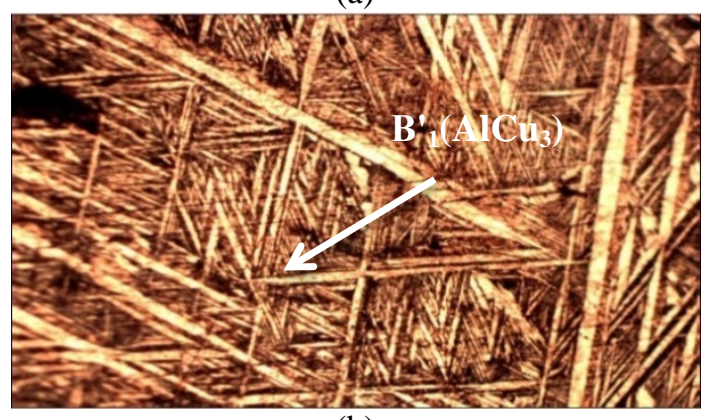

(b)

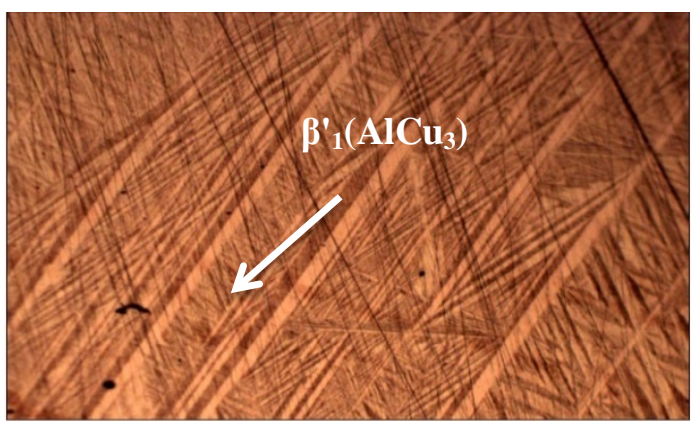

(c)

Figure 6: Effect of heat treatment on microstructure by optical microscope at magnification (10x)(a) $150^{\circ} \mathrm{C} 2 \mathrm{~h}$ oil quenching( b) $150^{\circ} \mathrm{C}$ 4h oil quenching (c) $150^{\circ} \mathrm{C}$ 6h oil quenching.

\subsection{Transformation temperature}

It is a method of determining transformation temperature start and finish of martensite and austenite by heating and cooling sample .temperature range from $\left(25\right.$ to $\left.200^{\circ} \mathrm{C}\right)$, heating rate $5^{\circ} \mathrm{C} / \mathrm{min}$ and cooling rate $5^{\circ} \mathrm{C} / \mathrm{min}$.

Table 2: Temperature start and finish of martensite and austenite by heating and cooling sample

\begin{tabular}{|c|c|c|}
\hline $\begin{array}{c}\text { Cu-Al-Be } \\
\text { alloy }\end{array}$ & $\begin{array}{c}\text { temperature } \\
\text { start }\left({ }^{\circ} \mathrm{C}\right)\end{array}$ & $\begin{array}{c}\text { temperature } \\
\text { finish }\left({ }^{\circ} \mathrm{C}\right)\end{array}$ \\
\hline Austenite & 36 & 68 \\
\hline martensite & 50 & 30 \\
\hline
\end{tabular}

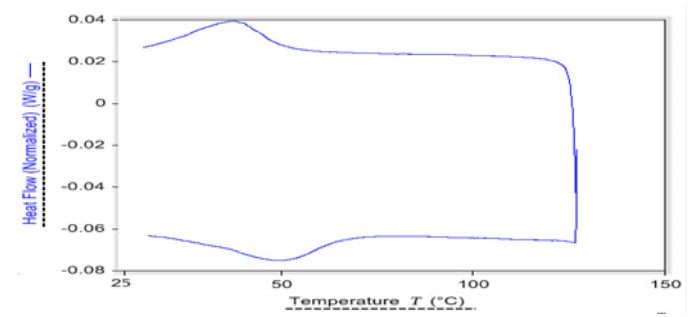

Figure 7: Deferential scanning calorimeter (DSC) of transformation temperature of Austenite and Martensite phase of $\mathrm{Cu}-\mathrm{Al}-\mathrm{Be}$ shape memory alloy as received.

\subsection{Corrosion testing.}

Corrosion test begin with open circuit potential for 60 minute to get equilibrium potential and then applied voltage under equilibrium potential approximately $500 \mathrm{mV}$ to get cathodic region and after this reach equilibrium potential then anodic region, passive region and transpassive. 


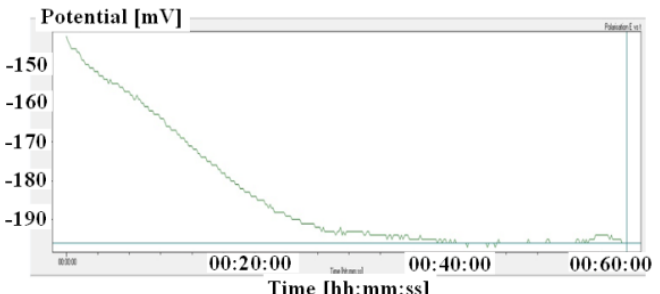

Figure 8: Open circiut potential (ocp) of Cu-AlBe shape memory alloy.

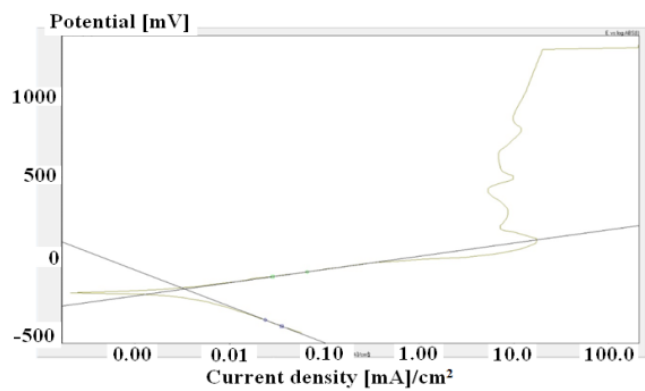

Figure 9: Tafal polarization of $\mathrm{Cu}-\mathrm{Al}-\mathrm{Be}$ shape memory alloy.

Aging martensite phase at $150^{\circ} \mathrm{C}$ 2hour show decrease in corrosion current and increase in corrosion potential, and when aging 4 hour also show increase in corrosion potential because these are less strain energy effect than quenching from high temperature in ice water that have high strain energy that can effect on corrosion potential, while aging 6hour will be show decrease in corrosion potential at salt ice water and water quenching because long aging time that will move nanoparticles along martenstie phase plate and along grain boundary that decrease corrosion potential . Also show increase pitting corrosion when aging 2 and 4 hour in oil quenching.effect of quenching media on corrosion potential show corrosion potential increase when quenching in oil than slat ice water and water.table below(3)(4) show effect of aging treatment on open circiut potential(ocp),corrosion current,corrosion potential and pitting corrosion and figure(10)(11) below show effect of aging treatment on corrosion current,corrosion potential.

Tables 3: Effect of heat treatment on open circuit potential.

\begin{tabular}{|l|c|}
\hline \multicolumn{1}{|c|}{ Heat treatment } & ocp $(\mathrm{mV})$ \\
\hline $800{ }^{\circ} \mathrm{C}$ and ice water quenching & -196 \\
\hline $\begin{array}{l}\text { Aging at } 1502 \text { hour and ice water } \\
\text { quenching }\end{array}$ & -191 \\
\hline Aging at 150 2 hour and water quenching & -180 \\
\hline Aging at 150 2 hour and oil quenching & -169 \\
\hline $\begin{array}{l}\text { Aging at 150 } 4 \text { hour and ice water } \\
\text { quenching }\end{array}$ & -146 \\
\hline Aging at 150 4 hour and water quenching & -192 \\
\hline Aging at 150 4 hour and oil quenching & -134 \\
\hline $\begin{array}{l}\text { Aging at 150 6 hour and ice water } \\
\text { quenching }\end{array}$ & -199 \\
\hline Aging at 150 6 hour and water quenching & -214 \\
\hline Aging at 150 6 hour and oil quenching & -195 \\
\hline
\end{tabular}

Table 3: Corrosion current density, corrosion potential and pitting corrosion

\begin{tabular}{|c|c|c|c|c|}
\hline Heat treatment & $\begin{array}{c}\mathrm{I}_{\text {corr }}(\mathrm{uA} / \\
\left.\mathrm{Cm}^{2}\right)\end{array}$ & $\begin{array}{c}\mathrm{E}_{\text {corr }}(\mathrm{m}) \\
\mathrm{V})\end{array}$ & $\begin{array}{c}\mathrm{E}_{\text {pitting }}(\mathrm{m} \\
\mathrm{V})\end{array}$ & $\begin{array}{c}\text { Corrosion } \\
\text { rate(mpy) }\end{array}$ \\
\hline $\begin{array}{c}\text { Shape memory } \\
\text { alloy }\end{array}$ & 3.32 & -196.1 & 1292.6 & 1.6324 \\
\hline $150^{\circ} \mathrm{C}$ 2h ice water & 1.3 & -191.2 & 1092 & 0.64 \\
\hline $150^{\circ} \mathrm{C}$ 2h water & 2.43 & -180.4 & 1093.2 & 1.195 \\
\hline $150^{\circ} \mathrm{C}$ 2h oil & 2.73 & -169.6 & 1255.8 & 1.3432 \\
\hline $150^{\circ} \mathrm{C}$ 4h ice water & 2.5 & -146.6 & 1172.7 & 2.085 \\
\hline $150^{\circ} \mathrm{C}$ 4h water & 1.62 & -151.6 & 955 & 0.7966 \\
\hline $150^{\circ} \mathrm{C}$ 4h oil & 2.81 & -134.2 & 1450 & 1.3817 \\
\hline $150^{\circ} \mathrm{C}$ 6h ice water & 3.21 & -198.7 & 1052.3 & 1.58 \\
\hline $150^{\circ} \mathrm{C}$ 6h water & 3.02 & -214.1 & 1155 & 1.5 \\
\hline $150^{\circ} \mathrm{C}$ 6h oil & 2.9 & -194.4 & 111.7 & 1.43 \\
\hline
\end{tabular}

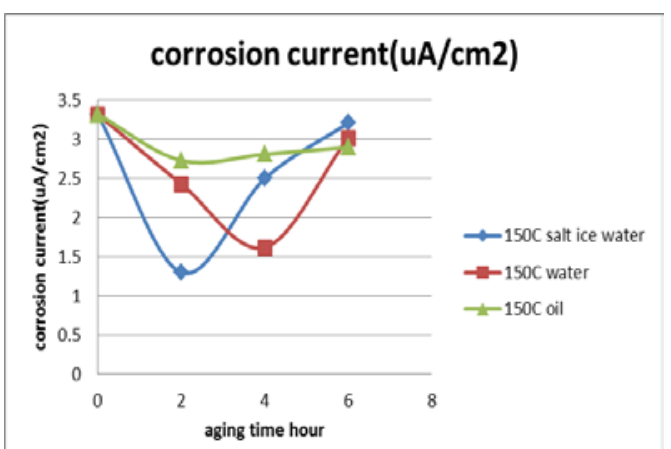

Figure 10: Effect of aging time, temperature and quenching media on corrosion current.

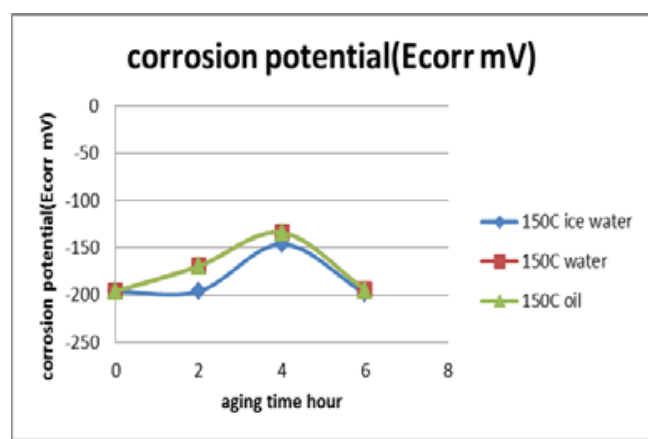

Figure 11: Effect of aging time, temperature and quenching media on corrosion potential.

Cyclic polarization of all samples not intersect with the passivation region and area of cyclic region is large that mean this alloy have high tendency to pitting corrosion and the area of curve by planimeter is $56 \mathrm{~cm}^{2}$.

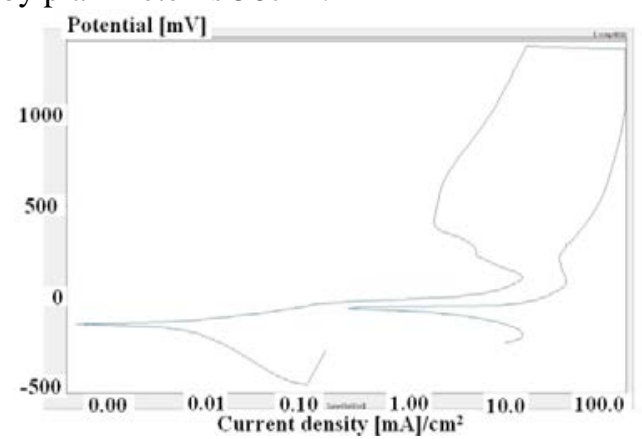

Figure (12): show cyclic polarization of $\mathrm{Cu}-\mathrm{Al}-$ Be shape memory alloy in simulation body fluid. 


\subsection{Microstructure after corrosion}

The effect of corrosion on microstructure of alloy studied by optical microscope. Picture of microstructure after corrosion test show general corrosion and localized corrosion. The corrosion Processes would occur mainly by the dissolution of both copper and aluminum. Samples present some zones with severe localized dealuminization[5,6].

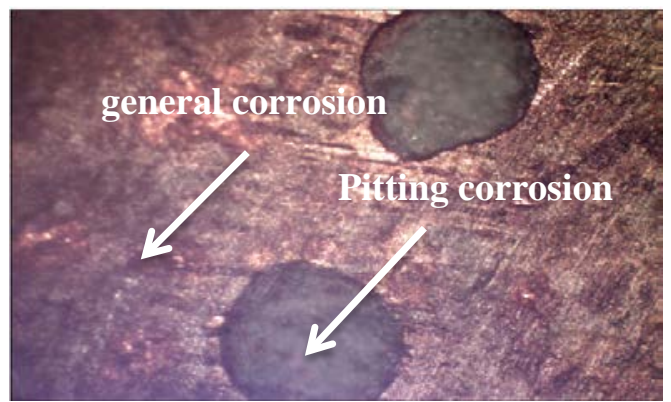

Figure 13: show microstructure of martensite phase general corrosion and localized corrosion in $\mathrm{Cu}-\mathrm{Al}-\mathrm{Be}$ shape memory alloy.
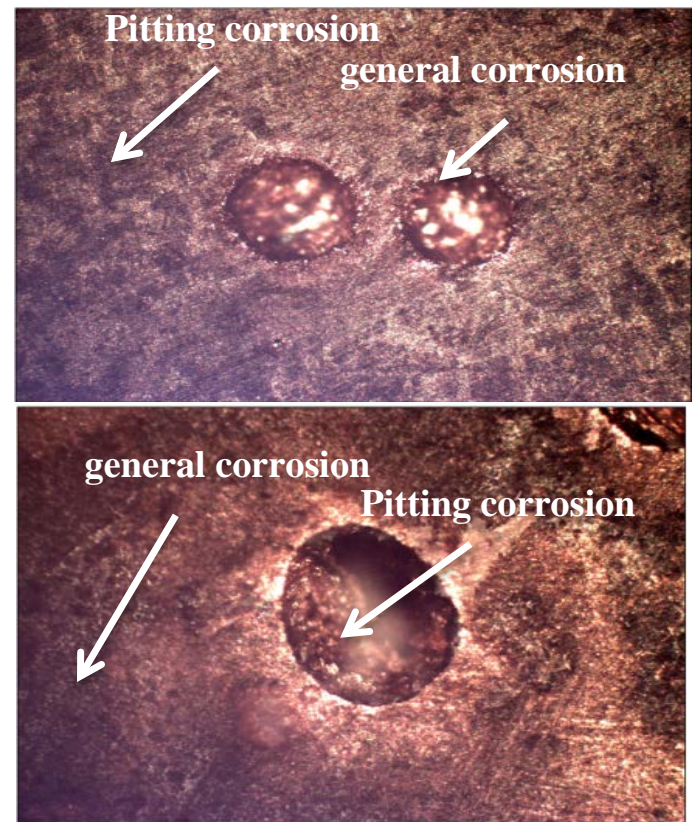

Figure 14: show microstructure of aging martensite phase general corrosion and localized corrosion in $\mathrm{Cu}-\mathrm{Al}$-Be shape memory alloy.

\section{Conclusions}

1- Open circuit potential of aging simple at 2 and 4 hour more than sample without aging.

2- Corrosion current density of sample at 2 and 4 hour less than simple without aging and corrosion potential more than simple without aging.
3- All simple approximately have same passivssion range.

4- Simple aging at 4 hour and oil quenching have high pitting potential than simple without aging.

5- Aging at 6 hour increase corrosion density and decrease corrosion potential.

\section{Acknowledgement:}

Acknowledgements may be directed to individuals or institutions that have contributed to the research or a government agency.

\section{Reference}

1. Shivasiddaramiah, A.G., Mallik, U.S., Mahato, R. and Shashishekar, C., 2017. Evaluation of corrosion behaviour of Cu-Al-Be-Mn Quaternary shape memory alloys. Materials Today: Proceedings, 4(10), pp.10971-10977.

2. Kustov S, Pons J, Cesari E , Morin M, Van Humbeeck J(2004) Athermal stabilization of $\mathrm{Cu}-\mathrm{Al}-\mathrm{Be} \quad \beta$ 1' martensite due to plastic deformation and heat treatment. Materials Science and Engineering A373(1):328-338.

3. Belkahla, S, Flores Zuniga H, and Guenin G (1993) Elaboration and characterization of new low temperature shape memory $\mathrm{Cu}-\mathrm{Al}-\mathrm{Be}$ alloys. Materials Science and Engineering: A169.1-2 : 119-124.

4. Kustov S, Morin M ,Cesari E (2004)On the instantaneous stabilization in $\mathrm{Cu}-\mathrm{Al}-\mathrm{Be} \beta 1^{\prime}$ martensite. Scripta materialia 50(2):219-224.

5. Montecinos S, and Simison S(2013) Corrosion behavior of $\mathrm{Cu}-\mathrm{Al}-\mathrm{Be}$ shape memory alloys with different compositions and microstructures.Corrosion Science 74: $387-$ 395.

6. Montecinos S, and Simison SN(2011) Study of the corrosion products formed on a multiphase CuAlBe alloy in a sodium chloride solution by micro-Raman and in situ AFM measurements.Applied Surface Science 257.17 : 7732-773 


\title{
تاثير التعتيق على مقاومة التاكل طور المارتنسايت لسبيكة نحاس-المنيوم- بريليوم
} الأاكرة الثكل

\author{
احمد عزيز حمزة \\ قسم هندسة الانتاج و المعادن
}

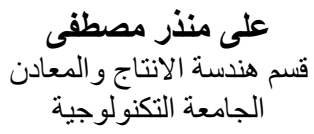
جعفر طاهر الحيدري قسم هندسة الانتاج و المعادن الجنان الجامعة التكنولوجية

الخلاصة - مقاصة

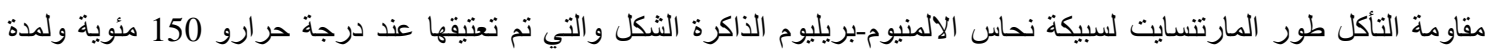

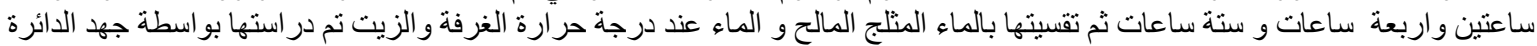

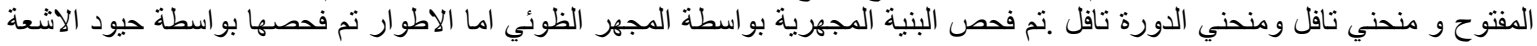

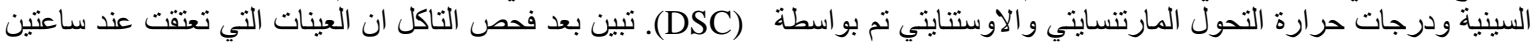

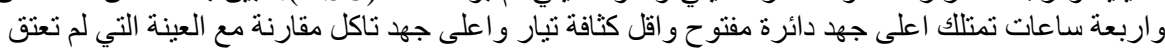

